\title{
PENGARUH PENGGUNAAN MODEL PEMBELAJARAN TEAM GAMES TOURNAMENT (TGT) DAN ROLE PLAYING TERHADAP HASIL BELAJAR PENDIDIKAN KEWARGANEGARAAN
}

\author{
Yusuf Alamsyah \\ Universitas Ibn Khaldun Bogor \\ e-mail: iyouz1974@gmail.com
}

\begin{abstract}
In today's student learning model, an innovation strategy is needed to improve student learning achievement, including team games tournaments (TGT) and Role-Playing models. This study aims to determine the differences in Civics learning outcomes between and role-playing models, in Madrasah Ibtidaiyah Ulil Amri's 4th-grade students. The design of the experiment is a randomized design to determine the effect of differences between the two models on student learning outcomes. The results showed that the Civics learning outcomes of students using the Team Games Tournament (TGT) learning method and the Role Playing learning method differed significantly. Based on the average mean TGT learning method has better results or values than the Role-Playing method.
\end{abstract}

Keywords: Citizenship Education, Team Games Tournament, role playing, learning strategies

Abstrak: Dalam model pembelajaran dewasa ini, diperlukan strategi inovatif untuk peningkatan prestasi belajar siswa, diantaranya dengan model pembelajaran Team games tournament dan role playing. Penelitian ini bertujuan untuk mengetahui perbedaan hasil belajar PKn yang menggunakan model pembelajaran Team Games Tournament (TGT) dan Role Playing, pada siswa kelas IV Madrasah Ibtidaiyah Ulil Amri. Rancangan yang digunakan adalah rancangan acak lengkap untuk melihat pengaruh perbedaan antara kedua perlakuan terhadap hasil belajar siswa. Hasil penelitian menunjukkan, dapat disimpulkan bahwa hasil belajar PKn siswa yang menggunakan metode pembelajaran TGT dan metode pembelajaran Role Playing berbeda secara signifikan. Dilihat dari rata-rata nilai hasil belajar, metode pembelajaran TGT memiliki nilai yang lebih baik dibandingkan metode Role Playing.

Kata Kunci: Pendidikan kewarganegaraan (PKn), TGT, Role Playing, strategi pembelajaran

\section{PENDAHULUAN}

Pendidikan memiliki pengaruh besar terhadap perkembangan suatu bangsa. Bangsa yang memiliki atau memperhatikan perkembangan ilmu pengetahuan akan memiliki kemajuan yang pesat karena dengan pendidikan tersebut orang akan memiliki kemampuan untuk bersikap dan bertingkah laku yang baik.

Hal tersebut diatas sejalan dengan cita-cita pendidikan yang tertuang dalam Undang-Undang Republik Indonesia Nomor 20 tahun 2003 tentang Sistem Pendidikan Nasional Bab II Pasal 3 yang menyebutkan bahwa pendidikan nasional berfungsi mengembangkan kemampuan dan membentuk watak serta peradaban bangsa yang bermartabat dalam rangka mencerdaskan kehidupan bangsa, bertujuan untuk 
mengembangkan potensi peserta didik agar menjadi manusia yang beriman dan bertaqwa kepada Tuhan Yang Maha Esa, berakhlak mulia, sehat, berilmu, cakap, kreatif, mandiri, dan menjadi warga negara yang demokratis serta bertanggung jawab.

Tujuan pembelajaran PKn yang dimaksud agar kita memiliki pola pikir pada sikap dan perilaku sebagai pola tindak yang cinta tanah air berdasarkan Pancasila. Melalui PKn warganegara termasuk siswa diharapkan mampu memahami, menganalisis dan menjawab masalah-masalah yang dihadapi oleh masyarakat, bangsa dan negara secara berkesinambungan dan konsisten dengan cita-cita dan tujuan nasional seperti yang tercantum dalam pembukaan UUD '45 (Sumarsono \& Masyur, 2002).

Mengacu kepada fungsi pendidikan nasional tersebut salah satu mata pelajaran yang mendukung adalah Pendidikan Kewarganegaraan (PKn). Pendidikan Kewarganegaraan (PKn) atau dikenal dengan Civic Education. Pendidikan Kewarganegaraan, khususnya pada jenjang SD/MI dilaksanakan dengan tujuan agar peserta didik memiliki kemampuan: (1) Berpikir secara kritis, rasional, dan kreatif dalam menanggapi isu kewarganegaraan; (2) Berpartisipasi secara aktif dan bertanggungjawab, dan bertindak secara cerdas dalam kegiatan bermasyarakat, berbangsa, dan bernegara, serta anti korupsi; (3) Berkembang secara positif dan demokratis untuk membentuk diri berdasarkan karakter-karakter masyarakat Indonesia agar dapat hidup bersama dengan bangsa-bangsa lainnya; dan (4) Berinteraksi dengan bangsa-bangsa lain dalam peraturan dunia secara langsung atau tidak langsung dengan memanfaatkan teknologi informasi dan komunikasi.

Berdasarkan hasil observasi awal di Ml Ulil Amri Kec. Ciawi Kab. Bogor pendidik masih cenderung menggunakan model pembelajaran konvensional pembelajaran ini masih berpusat pada pendidik sehingga peserta didik menjadi pasif atau kurang aktif dalam proses pembelajaran. Hal ini dapat menunjukkan bahwa hasil belajar yang diperoleh peserta didik pada mata pelajaran PKn masih kurang optimal, hal ini ditunjukkan dengan hasil nilai rata- rata peserta didik yang belum mencapai Kriteria Ketuntasan Minimal yang ditentukan yaitu 70.

Variasi strategi mengajar dibutuhkan agar peserta didik dapat belajar dengan lebih aktif dan efektif, serta tujuan yang ditetapkan dapat tercapai, dan yang sudah tercapai setidaknya bisa mencapai nilai yang lebih tinggi. Salah satu model pembelajaran inovatif yang dapat membuat proses pembelajaran menjadi lebih kreatif dan bermakna adalah model Teams Game Tournament (TGT) dan pembelajaran kooperatif tipe Role Playing.

Kedua model ini memiliki karakteristik yang hampir sama terutama dalam meningkatkan kreativitas belajar peserta didik. Menurut Slavin (2015) selaku tokoh yang mengembangkan TGT, model ini merupakan turnamen akademik dan menggunakan kuis-kuis dan sistem skor kemajuan individu dimana para peserta didik berlomba sebagai wakil tim mereka dengan anggota tim lain yang kinerja akademik sebelumnya setara seperti mereka.

Pada Teams Games Tournament (TGT), saat akhir proses pembelajaran akan melakukan turnamen yaitu menguji tingkat kemampuan masing-masing siswa dengan 
cara setiap turnamen sehingga diharapkan dapat mengajak siswa untuk berinteraksi, berdiskusi, bekerja sama menyelesaikan tugas dalam kelompok, serta berkompetisi dengan kelompok baru dalam turnamen (Trianto, 2011), sedangkan Role Playing mengajak peserta didik untuk lebih senang dan antusias dalam belajar, lebih mudah memahami konsep yang dipelajari. Metode ini pertama kali dibuat berdasarkan asumsi bahwa sangatlah mungkin menciptakan analogi otentik ke dalam suatu situasi permasalahan kehidupan nyata. Kedua, bahwa bermain peran dapat mendorong peserta didik mengekspresikan perasaannya dan bahkan melepaskannya. Ketiga, bawha proses psikologis melibatkan sikap, nilai dan keyakinan (belief) kita serta mengarahkan pada kesadaran melalui keterlibatan spontan yang disertai analisis.

Metode Role Playing adalah suatu cara penguasaan bahan-bahan pelajaran melalui pengembangan imajinasi dan penghayaratan peserta didik. Pengembangan imajinasi dan penghayatan dilakukan peserta didik dengan memerankannya sebagai tokoh hidup atau benda mati. Permainan ini pada umumnya dilakukan lebih dari satu orang. Hal itu bergantung kepada apa yang akan diperankan (Uno, 2007).

Role playing adalah salah satu teknik pengajaran di kelas yang mendorong siswa untuk berpartisipasi aktif, dan sangat membantu khususnya dalam proses belajar bahasa Inggris. Ketika kita berbicara tentang role playing sebagai metode pengajaran dapat dianggap sebagai masalah dapat diselesaikan secara lebih menjiwai karakter yang diperankan secara singkat, sehingga siswa dapat mengidentifikasi dengan karakter yang diperankan (Tompkins, 2001).

Gangel (2008) menyatakan bahwa role playing dapat didefinisikan sebagai tipe perilaku siswa dalam konteks tertentu. Misalnya pada bidang manajemen, perbedaan dalam peran identifikasi yang dapat dilihat sebagai konflik peran yang tidak cocok untuk seseorang atau oleh orang lain bermain peran sebagai metode pengajaran yang merupakan praktik yang dapat menjiwai peran dan mendorong diskusi dalam kelompok. Peneliti mendefinisikannya sebagai teknik bermain peran sebagai metodologi untuk mengajar yang merupakan representasi karakter dan diskusi peran dalam kelompok.

Meskipun demikian, dalam pelaksanaannya di Madrasah Ibtidaiyah masih banyak pendidik belum mencoba menerapkan keduanya dalam proses pembelajaran khususnya dalam mata pelajaran Pendidikan Kewarganegaraan, padahal bila ditelaah kedua model tersebut dapat menunjang secara cepat tercapainya tujuan pembelajaran atau kompetensi yang dikembangkan dalam mata pelajaran Pendidikan Kewarganegaraan. Misalnya keterampilan berpartisipasi secara demokratis dan bertanggung jawab akan dapat terwujud ketika peserta didik berdiskusi dan berinteraksi dalam dan antar kelompok. Dengan diskusi pula peserta didik akan berlatih menghargai pendapat orang lain, bekerjasama dan bertanggung jawab terhadap tugasnya.

Oleh karena itu, berpijak kepada karakteristik dari kedua model pembelajaran di atas, maka penulis mengadakan penelitian mengenai "Pengaruh pengunaan metode pembelajaran Teams Games Tournament (TGT) dan Role Playing terhadap hasil belajar pendidikan kewarganegaraan peserta didik kelas IV" dengan harapan menemukan model pembelajaran yang efektif dan inovatif dari model belajar konvensional seumumnya. 


\section{METODE PENELITIAN}

\section{A. Tujuan Penelitian}

Penelitian ini bertujuan untuk mengetahui perbedaan hasil belajar PKn yang menggunakan model pembelajaran Team Games Tournament (TGT) dan role playing, pada siswa kelas IV MI Ulil Amri.

\section{B. Tempat dan Waktu Penelitian}

Penelitian ini dilaksanakan pada peserta didik di Madrasah Ibtidaiyah, siswa kelas IV MI Ulil Amri. Waktu penelitian dilaksanakan pada semester genap tahun pelajaran 2018-2019.

\section{Metode Penelitian}

Penelitian ini menggunakan metode kuasi eksperimen (eksperimen semu) karena tidak semua aspek seperti tingkat intelegensi, sarana dan prasarana, motivasi atau pun minat dapat dikontrol.

Rancangan penelitian ini menggunakan Rancangan Acak Lengkap (RAL) dengan perlakuan model pembelajaran TGT dan Role Playing sebagai variabel bebas dan hasil belajar PKn sebagai variabel terikat. Masing-masing perlakuan memiliki jumlah sampel sebanyak 30 . Pengambilan sampel dilakukan dengan simple random sampling sehingga seluruh elemen populasi mempunyai kesempatan untuk menjadi sampel penelitian. Teknik analisis data yang digunakan dalam penelitian adalah Analisis Anova: Single factor dengan jumlah ulangan sama. Tujuan analisis ini untuk melihat perbedaan pengaruh antara siswa yang diberi perlakuan model pembelajaran TGT dan Role Playing.

Penelitian dilakukan pada bulan Desember-Januari, dilaksanakan pada semester genap tahun pelajaran 2018-2019. Prosedurnya adalah model pengajaran TGT dan Role Playing diiaplikasikan dalam setiap materi pengajaran selama waktu penelitian, kemudian diakhir penelitian dilakukan evaluasi untuk mengukur pengaruh hasil dari kedua model pembelajaran. Ruang lingkup materi yang akan diujikan adalah materi manfaat keberagaman karakteristik individu dalam kehidupan sehari-hari. Alat ukur yang digunakan adalah melalui uji tes prestasi belajar PKn.

Dalam melakukan tes dari hasil belajar Pendidikan Pancasila dan Kewarganegaraan (PKn) dilakukan dengan cara post test berupa test objektif pilihan ganda dengan 4 pilihan jawaban. Pilihan jawaban yang benar diberi angka satu dan jawaban yang salah diberi angka nol. Hasil dari tes prestasi belajar PKn tiap siswa di input menjadi data dalam analisis RAL.

Rancangan Acak Lengkap (RAL) memiliki asumsi bahwa selain perlakuan tidak ada faktor lain yang dianggap berpengaruh terhadap hasil pengamatan. Rancangan ini memiliki model analisis sebagai berikut.

$$
Y_{i j k}=\mu+\tau i+\varepsilon i j
$$


Keterangan:

$Y_{\mathrm{ijk}}=$ Nilai pengamatan pada perlakuan ke-i \& ulangan ke-j

$\mu=$ Nilai tengah umum

$\tau i=$ Pengaruh perlakuan ke-i

$\varepsilon i j=$ Galat percobaan pada perlakuan ke-i \& ulangan ke-j

\section{Populasi dan sampel penelitian}

Sampel adalah bagian dari jumlah dan karakteristik yang dimiliki oleh populasi tersebut. Apabila populasi besar dan peneliti tidak mungkin mempelajari semua yang ada pada pupulasi, maka peneliti dapat menggunakan sampel yang diambil dari populasi itu dan hasil yang dipelajari tersebut akan dapat diberlakukan untuk populasi (Sugiyono, 2017).

Pengambilan sampel dilakukan dengan simple random sampling Dipilih 1 kelas dari 3 kelas yang sudah belajar PKn dan terpilih kelas IV yang memiliki 2 rombongan belajar. Jumlah sampel yang diambil pada masing-masing kelas adalah sebanyak 30 orang baik pada perlakuan metode pembelajaran TGT maupun Role Playing. Sampel yang diteliti adalah peserta didik kelas IV pada MIS. Ulil Amri Kecamatan Ciawi Kabupaten Bogor yang berjumlah 2 rombongan belajar. Pemilihan ini didasarkan kepada alasan bahwa kedua rombongan belajar pada kelas IV di MIS Ulil Amri memiliki karakter dan tingkat kemampuan akademik yang relatif sama.

\section{E. Teknik Pengumpulan Data}

Terdapat dua jenis data yang dikumpulkan dalam penelitan ini, yaitu: data hasil belajar PKn yang diberi perlakuan model pembelajaran TGT dan yang diberi perlakuan model Role Playing. Jenis data tersebut terlebih dahulu diuji normalitas dan homogenitasnya.

\section{1) Uji normalitas}

Uji normalitas dilakukan untuk mengetahui pola distribusi dari masing-masing data kelompok, apakah terdistribusi normal atau tidak. Sebelum data dianalisis dilakukan terlebih dahulu uji kenormalan atau uji normalitas data. Pengujian normalitas data dalam penelitian ini dilakukan menggunakan uji Lilliefors dengan persamaan sebagai berikut.

Pengujian normalitas data dilakukan dengan menggunakan Uji Liliefors dengan menggunakan perangkat lunak ms. Excel. Pengujian ini dilakukan terhadap data hasil belajar siswa yang diberikan model pembelajaran Team Games Tournament dan Role Playing.

Tabel 1. Hasil Uji Normalitas Team Games Tournament

\begin{tabular}{lc}
\hline $\mathrm{L}_{0}$ & $\mathbf{0 , 1 3 5 8 3 3}$ \\
\hline L-tabel & 0,161 \\
\hline
\end{tabular}


Berdasarkan data pada Tabel 1 diketahui nilai $L_{0}$ sebesar 0,135 . Nilai $L_{0}$ tersebut dibandingkan dengan nilai $L$ tabel pada uji Liliefors. Diketahui nilai $L$ tabel pada Uji liliefors adalah sebesar 0,161 untuk jumlah sampel sebanyak 30 (n). Sehingga nilai $\mathrm{L}_{0}<\mathrm{L}$ tabel, maka dapat disimpulkan bahwa data hasil belajar peserta didik yang mengikuti model pembelajaran Team Games Tournament terdistribusi secara normal. Pengujian normalitas data Role Playing disajikan dalam Tabel 4.

Tabel 2. Hasil Uji Normalitas Role Playing

\begin{tabular}{lc}
\hline$L_{0}$ & $\mathbf{0 , 1 4 8 3 8 3}$ \\
\hline L-tabel & 0,161 \\
\hline
\end{tabular}

Berdasarkan data pada Tabel 2 diketahui nilai $L_{0}$ sebesar 0,148 . Nilai $L_{0}$ tersebut dibandingkan dengan nilai $L$ tabel pada uji Liliefors. Diketahui nilai $L$ tabel pada Uji liliefors adalah sebesar 0,161 untuk jumlah sampel sebanyak 30 (n). Sehingga nilai $\mathrm{L}_{0}<\mathrm{L}$ tabel, maka dapat disimpulkan bahwa data hasil belajar peserta didik yang mengikuti model pembelajaran Role Playing terdistribusi secara normal.

\section{2) Pengujian homogenitas}

Pengujian homogenitas data dilakukan dengan menggunakan perangkat lunak SPSS. Pengujian ini dilakukan terhadap data hasil belajar siswa yang diberi perlakuan model pembelajaran Team Games Tournament dan Model Pembelajaran Role Playing.

Berikut ini merupakan hasil pengujian Homogenitas data dengan menggunakan perangkat lunak SPSS.

Tabel 3. Hasil Uji Homogenitas dengan Model TGT

\begin{tabular}{cccc}
\hline Levene Statistic & $\mathrm{df} 1$ & $\mathrm{df2}$ & Sig. \\
\hline 3.486 & 1 & 28 & 0,072 \\
\hline
\end{tabular}

Berdasarkan Tabel 3, diketahui bahwa signifikansi (Levene) adalah sebesar 0,072 . Maka nilai tersebut lebih besar dari $\alpha=0,050$. Sehingga dapat dikatakan bahwa data dari model TGT berasal dari populasi yang homogen.

Data hasil pengujian homogenitas data hasil belajar siswa yang mengikuti model pembelajaran Role Playing yang dianalisis dengan SPSS dapat dilihat pada Tabel 4.

Tabel 4. Hasil Uji Homogenitas dengan Model Role Playing

\begin{tabular}{cccc}
\hline Levene Statistic & df1 & df2 & Sig. \\
\hline 1.195 & 1 & 28 & 0,284 \\
\hline
\end{tabular}


Berdasarkan Tabel 4, diketahui bahwa signifikansi (Levene) adalah sebesar 0,284 . Maka nilai tersebut lebih besar dari $a=0,050$. Sehingga dapat dikatakan bahwa data dari model Role Playing berasal dari populasi yang homogen.

\section{a. Uji Hipotesis}

Uji hipotesis yang digunakan dalam penelitian adalah Analisis Anova: Single factor dengan sel sama. Tujuannya untuk menguji signifikansi perbedaan pengaruh variabel bebas terhadap variabel terikat. Rancangan analisis data menggunakan rancangan acak lengkap dengan taraf signifikasi (a) 5\%. Hipotesis statistiknya adalah sebagai berikut (Gasperz, 1991).

$\mathrm{H}_{0}: \mathrm{T}_{\mathrm{i}}=\mathrm{T}_{2} \ldots=\mathrm{T}_{\mathrm{n}}=0$, yaitu tidak ada pengaruh perlakuan terhadap repon yang diamati

$H_{1}$ : Minimal ada satu $\mathrm{T}_{\mathrm{i}} \neq 0$, untuk $\mathrm{i}=1,2, \ldots, \mathrm{n}$ atau paling sedikit ada sepasang $\mathrm{T}_{\mathrm{i}}$ yang tidak sama

$\tau_{1}=$ Pengaruh perlakuan model pembelajaran TGT

$\tau_{2}=$ Pengaruh perlakuan model pembelajaran Role Playing

\section{TEMUAN DAN PEMBAHASAN}

\section{a. Deskripsi Data}

Data hasil penelitian dideskripsikan dalam penyajian data dengan distribusi frekuensi, histogram, mean, median, modus, standar deviasi, varians, dan skor. Deskripsi data disajikan dalam Tabel 5.

Tabel 5. Deskripsi Data Hasil Pembelajaran Metode TGT dan Role Playing

\begin{tabular}{lcc}
\hline \multirow{2}{*}{ Ukuran } & \multicolumn{2}{c}{ Variabel penelitian } \\
\cline { 2 - 3 } & TGT & Role Playing \\
\hline $\mathrm{N}$ & 30 & 30 \\
Mean & 83,17 & 73,67 \\
Median & 83,00 & 75,00 \\
Modus & 97,00 & 77,00 \\
Standar deviasi & 14,15 & 9,32 \\
Varians & 200,28 & 86,85 \\
Skor teoretik min & 0 & 0 \\
Skor teoretik max & 100 & 100 \\
Skor max & 100 & 93 \\
Skor min & 53 & 43 \\
\hline
\end{tabular}

Berdasarkan Tabel 5 dapat diketahui perolehan skor tertinggi adalah 100 dan terendah 53. Hasil deskripsi statistik menujukkan kelompok siswa yang diberikan model pembelajaran TGT memiliki rata-rata nilai 83,17; median 83 ; modus 97; standar deviasi 14,15; varians 200,28 . Sebaran skor disajikan dalam histogram frekuensi pada Gambar 1. 


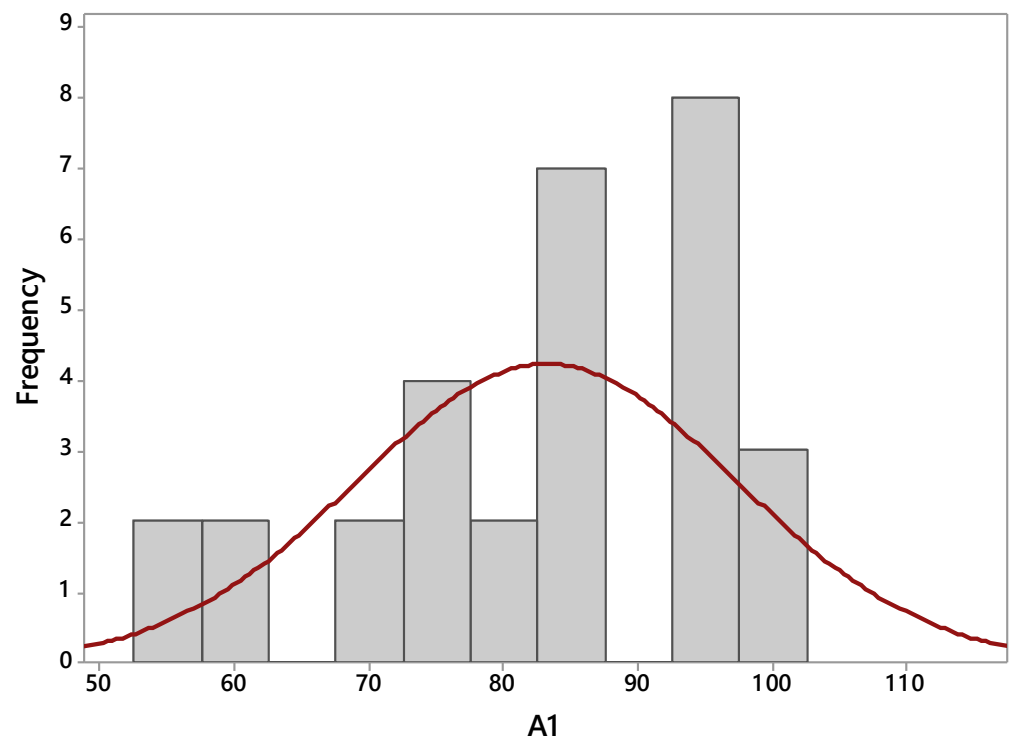

Gambar 1. Histogram frekuensi hasil belajar PKn dengan model TGT

Berdasarkan Tabel 5 dapat diketahui perolehan skor tertinggi adalah 93 dan terendah 43. Hasil deskripsi statistik menujukkan kelompok siswa yang diberikan model pembelajaran Role Playing memiliki rata-rata nilai 73,67; median 75,00; modus 77; standar deviasi 9,32 ; varians 86,85 . Sebaran skor disajikan dalam histogram frekuensi pada Gambar 2.

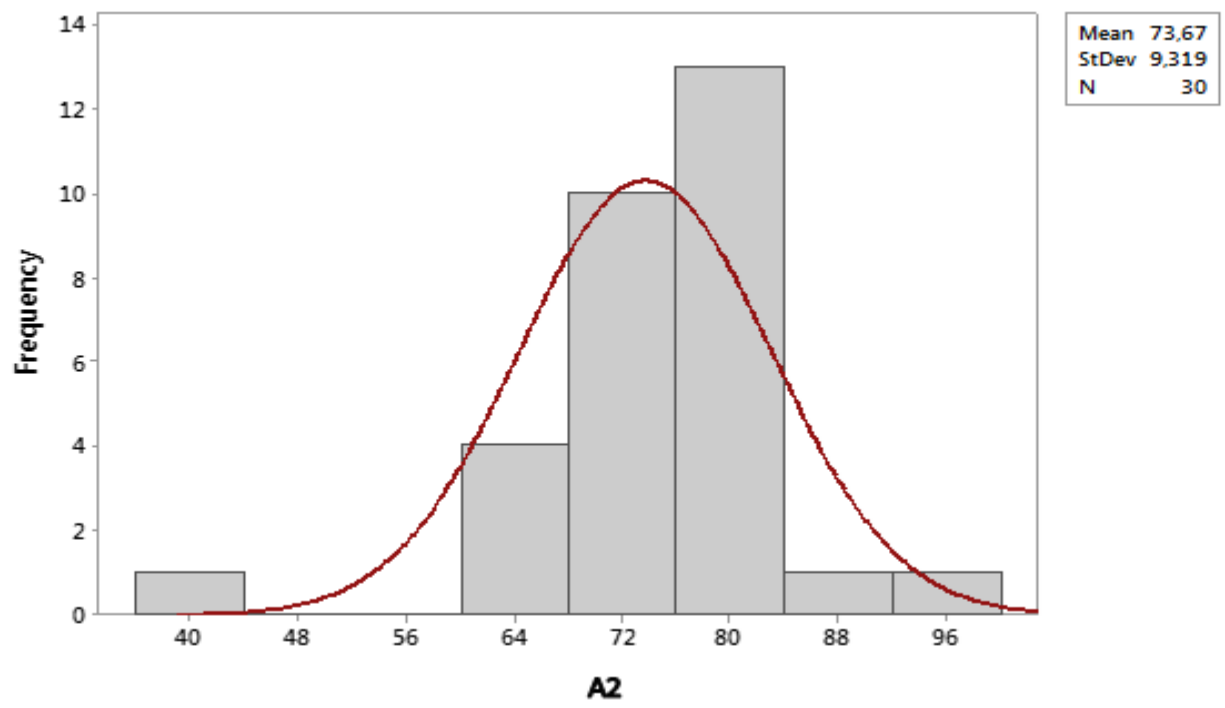

Gambar 2. Histogram frekuensi hasil belajar PKn dengan model Role Playing 


\section{a. Hasil Uji Hipotesis Penelitian}

Analisis data yang dilakukan dalam penelitian ini adalah menguji hipotesis dalam rancangan faktorial dengan menggunakan teknik analasis varians (ANOVA: Single factor) dengan perangkat lunak ms. Excel.

Hipotesis yang diajukan dalam penelitian ini adalah minimal ada pengaruh perbedaan dari kedua metode pembelajaran yang diberikan yaitu model Team Games Tournament (TGT) lebih baik dan berbeda secara signifikan dibandingkan dengan model pembelajaran Role Playing. Tabel 6 merupakan tabel yang menunjukkan rataan hasil model TGT dan Role Playing.

Tabel 6. Tabel Perbandingan Rataan Hasil Role Playing dan TGT

\begin{tabular}{lcccc}
\hline \multicolumn{1}{c}{ Groups } & Count & Sum & Average & Variance \\
\hline TGT & 30 & 2495 & 83,1667 & 200,2816 \\
Role Playing & 30 & 2210 & 73,6667 & 86,85058 \\
\hline
\end{tabular}

Berdasarkan rata-rata nilainya menunjukkan siswa yang mendapat model pembelajaran TGT memiliki nilai yang lebih tinggi (83.17) dibandingkan Role Playing (73.67). Tabel 7 yang menunjukkan hasil uji statistik dari model TGT dan Role Playing.

Tabel 7. Hasil Uji Statistik Model Pembelajaran TGT dan Role Playing

ANOVA

\begin{tabular}{|l|c|r|c|c|r|r|}
\hline Source of Variation & \multicolumn{1}{|c|}{$S$ S } & \multicolumn{1}{c|}{$d f$} & $M S$ & $F$ & $P$-value & $F$ crit \\
\hline Between Groups & 1353,75 & 1 & 1353,75 & $\mathbf{9 , 4 2 9 5}$ & $\mathbf{0 , 0 0 3 2}$ & $\mathbf{4 , 0 0 6 9}$ \\
\hline Within Groups & 8326,8333 & 58 & 143,5661 & & & \\
\hline Total & 9680,5833 & 59 & & & & \\
\hline
\end{tabular}

Berdasarkan hasil perhitungan, diketahui bahwa nilai $F_{\text {hitung }}$ dan $p$-value. Pada model pembelajaran berturut-turut sebesar 9,4295 dan 0,0032. Maka $p<0,05$, nilai $F_{\text {hitung }}$ yang lebih dari $\mathrm{F}_{\text {tabel }}(9,4295>4,0069)$ berarti Tolak $\mathrm{H}_{0}$ atau terima $\mathrm{H}_{1}$, sehingga dapat disimpulkan bahwa terdapat perbedaan yang signifikan pada hasil belajar PKn siswa yang diberikan model pembelajaran Team Games Tournament dengan model Role Playing. Kemudian berdasarkan rata-rata nilainya menunjukkan siswa yang mendapat model pembelajaran TGT memiliki nilai yang lebih tinggi $(83,17)$ dibandingkan Role Playing $(73,67)$.

Dalam proses belajar mengajar menggunakan metode Role Playing ini, siswa terlibat aktif dalam pembelajaran. Melalui metode Role Playing siswa harus memainkan peran-peran yang dikondisikan sesuai dengan keadaan sesungguhnya untuk lebih memahami secara langsung bentuk pengambilan keputusan bersama yang ada dalam kondisi dalam bidang tertentu, dalam hal ini terkait dengan penerapan materi Pendidikan kewarganegaraan dalam sehari-hari. Penerapan metode ini akan mendorong siswa mengekspresikan perasaannya, memahami langsung bentuk pengambilan keputusan bersama dan pesan moral yang terkandung dalam materi yang 
Yusuf Alamsyah - Pengaruh Penggunaan Model Pembelajaran

Team Games Tournament (TGT) dan Role Playing Terhadap

Hasil Belajar Pendidikan Kewarganegaraan

akan disampaikan. Pembelajaran yang melibatkan siswa secara langsung dengan menggunakan metode Role Playing akan membuat siswa tertarik pada pembelajaran, sehingga aktivitas dan hasil belajar siswa akan mengalami peningkatan. Namun demikian, dalam rangkaian pembelajaran dalam penelitian ini juga terdapat beberapa kendala, diantaranya adalah siswa belum terbiasa dengan materi ini sehingga diawal pembelajaran mereka sempat merasa canggung dan takut. Siswa yang terlibat perlu untuk diberikan motivasi, dorongan, dan bimbingan kepada siswa, sehingga mereka merasa percaya diri untuk mengikuti pembelajaran. Selain itu, sikap percaya diri diperlukan agar siswa dapat menjiwai role atau tokoh yang dimainkan (Sinanglingtyas et al., 2013).

Berdasarkan hasil yang diperoleh, siswa yang diberikan metode pembelajaran Team Games Tournament (TGT) memiliki rata-rata nilai hasil belajar PKn yang lebih tinggi. Didukung oleh hasil uji statistika dengan $p$-value $0,0032(p<0,05)$, maka kedua metode dapat dikatakan berbeda secara signifikan. Proses pembelajaran dengan metode pembelajaran kooperatif Team Games Tournament dalam kelas eksperimen dapat meningkatkan sifat kooperatif antar siswa. Maka para siswa akan saling dapat menyampaikan bertukar ide hasil pemahaman dari materi PKn yang diberikan, sehingga materi akan semakin dipahami secara merata oleh siswa yang lainnya.

Sari et al. (2012) menjelaskan tentang peningkatan hasil belajar dengan menggunakan model pembelajaran kooperatif team games tournament dalam materi permintaan, penawaraan dan terbentuknya harga pasar. Dari hasil penelitian diketahui penggunaan model pembelajaran Team Games Tournament lebih efektif dari pada model pembelajaran konvensional khususnya materi pokok permintaan, penawaran, dan terbentuknya harga pasar. Hal ini dapat dibuktikan dari rata-rata nilai post test untuk kelas eksperimen sebesar 76,77 dan kelas kontrol sebesar 73,00. Hal ini menunjukkan bahwa kelas eksperimen nilainya lebih tinggi dibandingkan kelas kontrol sebesar yang memiliki peningkatan sebesar $83,87 \%$.

Selain itu, metode TGT dapat memberikan rasa percaya diri siswa dalam berpartisipasi aktif di dalam kelas. Pemberian kesempatan siswa untuk berpartisipasi dapat membuat siswa lebih aktif dalam proses belajar mengajar, khususnya mata pelajaran PKn. Slavin (2015), menyatakan bahwa pembelajaran kooperatif merupakan sarana yang sangat baik untuk meningkatkan pencapaian atau prestasi peserta didik. Hal itu disertai pencapaian positif lainnya, yaitu dapat mengembangkan hubungan antar kelompok, penerimaan atau toleransi terhadap teman yang cenderung lemah dalam menerima materi pelajaran, serta meningkatkan rasa percaya diri dalam menyampaikan pendapat. Berdasarkan penelitian Micheal (2011) menyatakan bahwa metode kooperatif TGT berdampak positif dalam pencapaian materi, retensi dan sikap siswa terhadap metode pengajaran siswa. Hasil penelitian menunjukkan bahwa tes prestasi skor untuk kelompok TGT adalah 52,99, sedangkan kelompok kontrol adalah 50,13. Ini menyiratkan bahwa kelompok TGT memiliki tes prestasi yang baik dibandingkan dengan kelompok kontrol. Kelompok perlakuan menunjukkan sikap positif terhadap TGT sebagai strategi pengajaran untuk pendidikan ekonomi. 
Susilowati (2014) berpendapat bahwa model pembelajaran TGT mampu membuat siswa belajar lebih aktif dan termotivasi dalam memecahkan soal-soal latihan. Penggunaan model ini dapat menumbuhkan rasa tanggung jawab terhadap individu sekaligus kekompakan atau teamwork yang terjalin selama kegiatan diskusi kelompok. Dalam penelitiannya nilai rata-rata siswa untuk kompetensi dasar meningkat dari 61,51 menjadi 84,07. Hal ini menunjukkan pengaruh inovasi dan aplikasi metode belajar yang tepat mampu memberikan pengaruh signifikan dalam meningkatkan prestasi belajar siswa disekolah.

\section{SIMPULAN}

Berdasarkan hasil penelitian, dapat disimpulkan bahwa hasil belajar PKn peserta didik MI Ulil Amri tingkat IV yang menggunakan metode pembelajaran Team Games Tournament (TGT) dan metode pembelajaran Role Playing berbeda secara signifikan. Dilihat dari rata-ratanya metode pembelajaran TGT memiliki hasil atau nilai yang lebih baik dibandingkan metode Role Playing.

\section{REFERENSI}

Gangel, K. O. (2008). Teaching through role playing. Tersedia di: http://bible. org/seriespage/teaching-through-role-playing [29 Juni 2010].

Gasperz, V. (1991). Rancangan Percobaan. Jakarta: Armico.

Micheal, M. V. W. (2011). The Effects Of Teams Games Tournament On achievement, Retention, and Attitude Economics Education Student. International journal, Vol 26 No 3, hal 183, 193.

Sari, R. E. K., Hadi, S., \& Prishardoyo, B. (2012). Upaya Peningkatan Hasil Belajar Dengan Menggunakan Model Pembelajaran Kooperatif Team Games Tournament (Materi Permintaan, Penawaraan dan Terbentuknya Harga Pasar). Economic Education Analysis Journal, 1(1).

Sinanglingtyas, R. (2013). Penerapan Metode Role playing untuk Meningkatkan Aktivitas dan Hasil Belajar Siswa Kelas V dalam Pembelajaran PKn Pokok Bahasan Bentuk-Bentuk Keputusan Bersama di SDN Tukum 01 Lumajang. Jurnal Pendidikan UNEJ, 1(1), 1-5.

Slavin, Robert E. (2015). Cooperatif Learning: Teori, riset, dan praktik. Bandung: Nusa Media.

Sugiyono. (2017). Metode Penelitian Kuantitatif, Kualitatif dan R \& D. Bandung, Alfabeta,

Sumarsono dan Mansyur. (2002) Pendidikan Kewarganegaraan. Jakarta : Gramedia Pustaka Utama.

Susilowati, D. (2014). Studi Komparasi Hasil Belajar Akuntansi Dengan Penerapan Metode Pembelajaran Teams Games Tournament (Tgt) Dengan Metode Ceramah Bervariasi Pada Kompetensi Dasar Jurnal Khusus Siswa Kelas Xii Ips Sma Muhammadiyah 01 Pati. Economic Education Analysis Journal, 2 (3). 7 hal. 
Tompkins, P.K. (2001). The Role Playing. Simulation. (TESL, Vo IV No 8, Agues. P4).

Trianto. (2011) Model-model Pembelajaran Inovatif Berorientasi Konstruktivistik Jakarta: Prestasi Pustaka.

Uno, H. B. (2007). Model pembelajaran menciptakan proses belajar mengajar yang kreatif dan efektif. Jakarta: Bumi Aksara. 